\section{Mucous Colitis}

"Perplexed" writes: I have a female patient, aged 54 years, suffering from mucous colitis, which can be fairly well controlled by diet and occasional medicine. But there are two symptoms which are entirely unaffected by any treatment so far given, either locally or generally. These are a painful tongue, especially at the base, and a severe "bitterness" accompanying it. Practically everything taken by mouth aggravates both symptoms. I shall be grateful for any advice as to treatment.

\section{"Calcium Phosphate Stomatitis"}

Dr. J. St. Clair writes: A patient of mine has been complaining for a considerabie time of very dry lips. This seems to be due to the condition of the mouth, which is hot and dry and coated with a grit-like fine sand. This "grit" can be taken between the teeth and "bitten." Collections of saliva-in the absence of dentures-reveal this "grit" in the form of a white deposit, consisting chiefly of calcium phosphate, with traces of calcium carbonate and organic matter. Various treatments have been tried: pilocarpine, mouth-washes, glycerin smeared over the mouth and lips, and potassium acetate to act as a diuretic and prevent, if possible, the formation of calcium phosphate, but so far no success has attended our efforts. Any suggestions as to the cause and cure of this condition would be appreciated.

\section{Chromidrosis}

Dr. J. A. Noble (Lowthorpe, Bournemouth) writes in reply to Dr. Gibb (Journal, February 29th, p. 455): The staining is due to a mould growing on the axillary hair. The mycelium may be pearly-white, yellow, or brick-red, and forms excrescences on the hair, increasing its size up to ten diameters. The spores are very resistant to disinfectants and to heat, and will reinfect the patient if the same underclothes are worn again a year later. A minute daily application of ung. resorcin co., with shaving and new underclothes, will effect a cure in fourteen days. If Dr. Gibb will write I will send him the name of a proprietary preparation which is less messy and equally efficacious.

\section{Arthritis and Water Supply}

Dr. Mea Frazer (Belfast) writes in reply to "G. L. P." (March 7th, p. 513): I have had experience of cases developing arthritis following sudden changes from soft to hard water. Treatment in these patients also made no appreciable difference. In each case I ordered the installation of a "water softener," one supply from which was used for all cooking and drinking purposes. The results were most satisfactory, all symptoms disappearing in about a week. The apparatus is available at a very small cost. There are certain types of rheumatism which owe their origin to an excess of calcium salts. I presume the " hardness" in this case is due to lime.

\section{Stammering}

Dr. R. Macdonald Ladell (Birmingham) writes: Stammering is essentially a symptom of a neurotic attitude to life. It may be one of many symptoms, or the only obvious one. In either case psychotherapy is applicable, and should be tried. The resistance of this particular symptom is, I believe, due to its value to the patient. All neurotic symptoms have, of course, such value, but the symptom of stammering is a particularly easy defence mechanism, since it prevents any great social demands being made on the stammerer, and at the same time gives him an obvious excuse for his failure to achicve his goal in life. This is shown very clearly during school life, when the stammerer is not likely to be called upon to aiswer questions in class, and probably has "allowances" made for him at every turn. A wider experience of life may show that the disadvantages of such a disability are greater than the advantages thus obtained, and the sufferer may make a real and successful effort to face reality, with consequent improvement. One sees people in whom the slight impediment which remains is almost in the nature of a social asset, and there is no inducement to be deprived of it.

\section{Income Tax}

Taking over Additional Practice

"H. R." took over an additionai practice as from July 1st, 1933. He has now received an application for additional tax for the year commencing April 5th, 1933, " for earnings of the new practice for the year 1932-3."

${ }_{*}^{*}$. The income of the practitioner-on an earnings basis -is increased as from the date of taking over the additional practice, and some alteration in the assessment that would otherwise have been made is legally required. This is usually done by adding to the assessment on the old practice the amount of the current year's earnings of the additional practice-for example, in the present case the normal assessment for 1933-4 would be increased by the earnings of the additional practice for the nine months to April 5th, 1934. It happens not infrequently that owing to the amalgamation of the practices the earnings of the addition cannot. be separated, and an estimate is made of the additional earnings based on past profits. Applying this to "H. R.'s" case the Revenue's procedure would seem to be legitimate, provided the amount of the additional assessment is reasonable -for example, that it takes into account that he had the additional earnings for nine months only of 1933-4, and on the assumption that his expenses were not substantially greater than those of his predecessor.

\section{LETTERS, NOTES, ETC.}

\section{To the Deaf all Films are Silent}

Dr. P. D. Strachan (Maseru, Basutoland) writes: There must be many totally deaf persons to whom the silent cinema entertainment, now obsolete, was a source of badly needed recreation. The advent of the talking machine has left them out in the cold. A little over two years ago I saw and heard a French cinema play in London, in which were flashed upon a part of the screen a sufficient number of "captions" in English to enable those ignorant of "French to follow the story. Surely the addition of such captions to all films would add but a small percentage to the enormous amount of money that is spent on their production. It has occurred to me that our Association ought to take the matter up with the principal producers. Let us not forget that to the deaf all films are silent.

\section{Foreign Visitors to France}

The French National Touring Office (Office Français du Tourisme), 56, Haymarket, S.W.1, informs us that foreign visitors in possession of either a passport or an identity paper, according to the nationality, are allowed to travel in France, Algeria included, for two months without additional formalities or payment of any taxes. If they wish to extend their stay for a period not exceeding four months (making six months in all) foreign tourists can obtain a "Carte de Tourisme" free of charge. Before leaving their own country they should apply for this card to the French consul in their district. If they had not cbtained the card before leaving they could make application to the Préfet of the Department where they stay in France. Tourists wishing to remain in that country for a period exceeding six months must apply in France to the nearest Préfet for the usual "carte d'identité," the cost of which has been reduced from 220 to 160 francs, and the validity extended from two to three years.

\section{Nursery Biscuits}

The manufacturers of Robb's nursery biscuits and biscuit powders give the following interesting account of the history of these preparations. Dr. Benjamin Golding was horrified by the huge infant mortality in the notorious Seven Dials district of London, and made investigations to discover a food which would prevent rickets and promote the general health of infants. He finally evolved what he considered to be the perfect food, and treated thousands of infants gratuitously. An analysis of the biscuits has shown protein content 10 per cent.; fat content 6 per cent. insoluble carbohydrates (starch altered by baking), 60 per cent. ; and soluble carbohydrates, 16 per cent. The makers point out that their biscuits and foods have maintained a high reputation for more than a century.

\section{Corrigendum}

In our note on the meeting of the Hcalth and Housing Committee of the Conservative Party (Journal, March 21st p. 613) Mr. Murray N. Phelps was reported to have said that "in the first ten years the number of cremations had increased to 2,800." "This should, of course, have read "in the last ten years, etc."

\section{Vacancies}

Notifications of offices vacant in universities, medical colleges, and of vacant resident and other appointments at hospitals, will be found at pages $45,46,47,48,49,50,51$, and 54 of our advertisement columns, and advertisements as to partnerships, assistantships, and locumtenencies at pages 52 and 53.

A short summary of vacant posts notified in the advertisement columns appears in the Supplement at page 135 . 